Shields, R., Mulholland, A. T. \& Elmslie, R. G. (1966). Gut 7, 686.

Smith, R. H. (1958). Biochem. F. 70, $20 \mathrm{r}$.

Smith, R. H. (1959). Biochem. F. 71, 306.

Smith, R. H. (1962). Biochem. F. 83, 151 .

Smith, R. H. (1963). Nature, Lond. 198,161 .

Smith, R. H. (1964a). Nord.VelMed. 16, suppl. 1, p. I43.

Smith, R. H. (1964b). F. Physiol., Lond. 172, 305.

Smith, R. H. (1966). F. Physiol., Lond. 183, 532 .

Smith, R. H. \& McAllan, A. B. (1966). Br. F. Nutr. 20, 703.

Smith, R. H. \& McAllan, A. B. (1967). Proc. Nutr. Soc. 26, xxxii.

Smith, R. H., McAllan, A. B. \& Hill, W. B. (1968). Proc. Nutr. Soc. 27, 48 A.

Storry, J. E. (1961a). F. agric. Sci., Camb. 57, 97.

Storry, J. E. ( ( $96 \mathrm{~s} b)$ ). F. agric. Sci, Camb. 57, 103.

Stout, P. R., Brownell, J. \& Burau, R. G. (1967). Agrun. F. 59, 2 I.

Suttle, N. F. \& Field, A. C. (1967). Br. Y. Nutr. 21, 819.

van Weerden, E. J. (1961). F. agric. Sci., Camb. 56, 317 .

Wallis, G. C., Palmer, L. S. \& Gullickson, T. W. (1935). F. Dairy Sci. 18, 213.

Wasserman, R. H., Kallfelz, F. A. \& Comar, C. L. (196r). Science, N.Y. 133,883.

Webling, D. D'A. \& Holdsworth, E. S. (rg66). Biochem. J. roo, 652.

Young, V. R, Lofgreen, G. P. \& Luick, J. R. (I966). Br. F. Nutr. 20, 795.

Young, V. R., Richards, W. P. C., Lofgreen, G. P. \& Luick, J. R. (1966). Br. F. Nutr. 20, 783.

\title{
Diarrhoea of nutritional origin
}

By J. H. B. Roy, National Institute for Research in Dairying, Shinfield, Reading

\section{Definition}

For the purpose of this paper, diarrhoea will be defined as the condition in which faeces containing less than I $2 \%$ dry matter are produced. It may be the result of poor absorption of water from, or increased secretion of water into, the alimentary tract, or in certain cases a reduced excretion of faecal dry matter.

\section{Economic importance}

The economic importance of diarrhoea in the ruminant animal is mainly of relevance in the nutrition at the pre-ruminant stage. In a recent survey of calf wastage (Leech, Macrae \& Menzies, I 968) 8.9\% of 40000 calves were affected with diarrhoea on some occasion during the Ist year of life. The cause of death in $44.9 \%$ of $35^{\circ}$ post-mortem examinations was classified as being due to gastrointestinal disorders, with a further $24.8 \%$ resulting from septicaemia. Since an earlier survey of 2046 post-mortem examinations showed that Escherichia coli was associated with $46 \%$ of deaths up to 6 months of age and Salmonella with $24 \%$ (Veterinary Investigation Service, I964), the great majority of the gastro-intestinal disorders are clearly associated with colibacillosis. Most of the mortality from diarrhoea occurs at a young age and, in the survey of Leech et al. (1968), the probability of death at any time in home-bred calves was about equal to the reciprocal of age, and percentage mortality up to age $W$ (in weeks) was equal to $\log _{e} W+r^{\circ} 72$. 
The pre-ruminant calf is much more prone to diarrhoea than the calf that has been weaned at a young age. Thus, for eighty calves that received ad lib. or restricted amounts of liquid or dry diets, the mean numbers of days on which diarrhoea occurred during the first $\mathrm{I}_{3}$ weeks of life were: for pre-ruminant calves, 7 on ad lib. and 5 on restricted feeding; on the other hand, for ruminant calves (weaned at 5 weeks of age), the number of days was $I$ on both $a d l i b$. and restricted feeding. There is also a breed difference in susceptibility to diarrhoea; the mean numbers of days on which diarrhoea occurred for eighty calves given liquid diets during the first 13 weeks of life were: for Jersey calves $4 \cdot 6$, for Ayrshire $3 \cdot 5$ and for Friesians ${ }^{*} 4$.

\section{Fermentative and putrefactive diarrhoea}

In man, diarrhoea has been classified as either fermentative or putrefactive, according to the qualitative and quantitative changes that occur in the bacterial flora (Weijers $\&$ van de Kamer, 1965). There is normally a balance between the saccharolytic flora, consisting mainly of lactobacilli, and the saccharo-proteolytic flora, consisting mainly of the Enterobacteriaceae, including E. coli, and Clostridia. The dominance of the saccharolytic flora and the production of fermentative diarrhoea is associated with the fermentation of non-absorbable carbohydrates, whilst the dominance of the saccharo-proteolytic flora is associated with abnormal amounts of peptides and proteins in the chyme. In the infant, this may result from the limited functional capacity of the proteolytic enzyme systems (Werner, 1948).

Although the diarrhoea is basically of nutritional origin, the resultant change in bacterial flora allows the production of toxic substances, which cause hyperperistalsis and hypersecretion together with diminished water absorption. In fermentative diarrhoea, the toxic substances consist of increased amounts of low molecular organic acids and lactic acid, and the $\mathrm{pH}$ of the faeces is usually acid, although secondary putrefaction may occur. With putrefactive diarrhoea, the endproducts of the bacteria include amines and endo- and exo-toxins.

In general, the consequences of putrefactive diarrhoea are much more serious than with the fermentative form, partly because the condition is self-perpetuating, since even on a nitrogen-free diet, $\mathrm{N}$ is released from lesions in the intestinal mucosa. The extent of the damage caused to the epithelial cells depends on the level of amine oxidases and antibodies present. Although, in the infant, the circulating antibodies are transferred placentally, IgA obtained from the ingestion of colostrum may have a protective function in the intestinal mucosa (Schultze \& Heremans, 1966). The faeces produced in putrefactive diarrhoea is usually of alkaline reaction.

\section{Putrefactive diarrhoea in the pre-ruminant calf}

To what extent is diarrhoea in the young calf comparable to that found in the infant?

The faecal losses that occur in diarrhoea in the calf have been estimated by Blaxter \& Wood (I953) (Table r), and the changes in blood composition and myocardial potassium by Fisher (1965) and Fisher \& McEwan ( 1967 ) (Table 2); it is not proposed to deal further with these aspects. 
Table 1. Amounts of various constituents excreted daily in the faeces of calves with diarrhoea compared with those in the faeces of normal calves (Blaxter \& Wood, 1953)

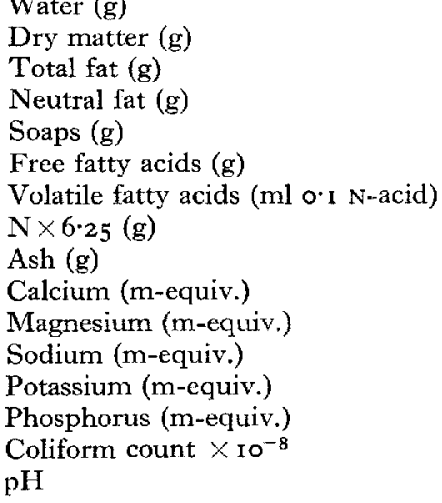

\begin{tabular}{|c|c|c|}
\hline $\begin{array}{l}\text { Normal } \\
\text { calves }(a)\end{array}$ & $\begin{array}{l}\text { Calves with } \\
\text { diarrhoea }(b)\end{array}$ & Ratio, $b: a$ \\
\hline $5 \times \cdot 0$ & 927 & $18 \cdot 2$ \\
\hline $12 \cdot 5$ & 93.5 & $7 \cdot 5$ \\
\hline $4 \cdot I$ & $37^{\circ} 4$ & $9^{\cdot I}$ \\
\hline I'5 & $10 \cdot 6$ & 7.0 \\
\hline $\mathrm{I} \cdot 9$ & $8 \cdot 3$ & $4 \cdot 4$ \\
\hline 0.7 & $18 \cdot 5$ & $26 \cdot 4$ \\
\hline $164 \cdot 0$ & $1056 \%$ & $6 \cdot 4$ \\
\hline $5 \cdot 5$ & $4 I \cdot 0$ & $7 \cdot 5$ \\
\hline$I \cdot 5$ & $10 \cdot 6$ & $7 \cdot 1$ \\
\hline $21 \cdot 6$ & $98 \cdot 8$ & \\
\hline $11 \cdot 4$ & 240 & 37 \\
\hline $5^{\circ} \circ$ & $41 \cdot 6$ & \\
\hline $2 \cdot 2$ & $39 \cdot 9$ & II'3 \\
\hline $2 I \cdot 0$ & $94^{\circ} 0$ & $4 \cdot 4$ \\
\hline I $18 \cdot 0$ & 2907.0 & $24 \cdot 6$ \\
\hline $6 \cdot 8$ & $6 \cdot 0$ & - \\
\hline
\end{tabular}

Table 2. Values for various characteristics of the blood and myocardial muscle of normal calves and of those with diarrhoea that survived or died (Fisher, 1965; Fisher E McEwan, 1967)

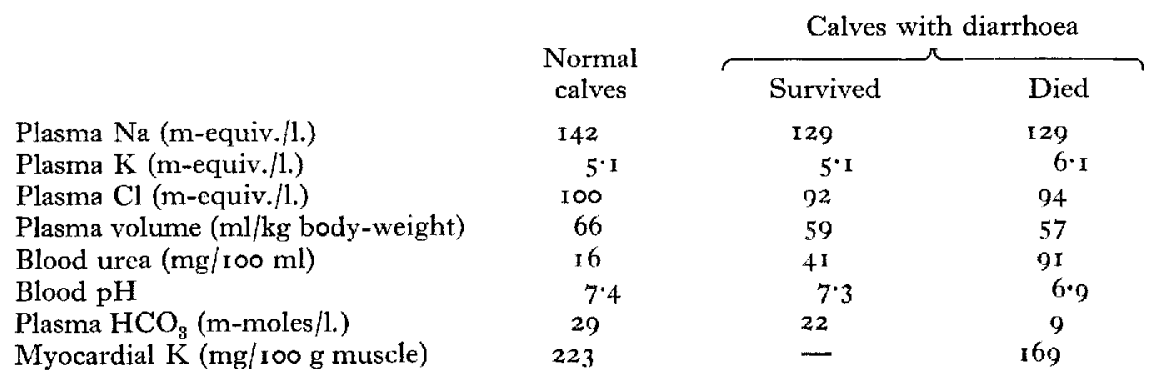

The newborn calf, although very susceptible to $E$. coii septicaemia if deprived of colostrum is, in general, well protected if it has ingested sufficient colostrum of high immune globulin content as soon after birth as possible. On the other hand, if it is given a small quantity of colostrum, or even a large quantity of colostrum under conditions of high 'infection' as evidenced by the dominance of particular strains of $E$. coli, the calf is particularly susceptible to an $E$. coli localized intestinal infection resulting in severe diarrhoea, dehydration and often death. However, if calves have had sufficient colostrum, during the period that the intestine is permeable to the transfer of antibodies to protect against a septicaemia, then additional colostrum given after the period of permeability tends to reduce diarrhoea, possibly by localized action in the intestine (Roy, 1956 , 1964 ).

The first organisms to colonize the alimentary tract of the normal neonatal calf are E. coli, streptococci and Clostridium welchii. These are followed by the lactobacilli which become the most numerous organisms in the stomach and small intestine (Smith, 1965 ). The temporary dominance of the first organisms to colonize has been 
attributed to the high $\mathrm{pH}$ of the abomasum contents at this time, and the decline of these organisms has been associated with the subsequent fall in $\mathrm{pH}$.

Within 5.5 h after birth, $E$. coli are restricted mainly to the ileum and the large intestine, but by $8.5 \mathrm{~h}$ after birth, they are found in the abomasum at a level of ${ }_{10}{ }^{3} / \mathrm{ml}$. In the duodenum, the viable $E$. coli count reaches a peak at $\mathrm{I}-4$ days of age, and in normal healthy calves it declines to a very low level at io days of age, presumably because of the increasing dominance of the lactobacilli. In contrast, calves whose deaths are associated with an $E$. coli localized intestinal infection still have viable counts of $10^{7}-10^{8} / \mathrm{ml}$ in the duodenum at the latter age (Ingram, 1962).

Earlier experiments with a very large number of calves (Shillam, Dawson \& Roy, I960; Shillam \& Roy, I961, I963a,b,c; Shillam, Roy \& Ingram, I $962 a, b, c)$ showed that the quality of the milk substitute diet given directly after the colostrumfeeding period was of paramount importance as a factor predisposing to $E$. coli localized intestinal infection. Milk substitutes are based to a large extent on skimmilk powder. Processing of skim milk that results in a marked denaturation of the whey proteins is detrimental to the calf ('Table 3). Associated with the denaturation of the whey proteins are a reduction of ionizable calcium, release of SH groups, poor clotting ability by rennet, and reduced digestibility, but no loss of biological value, of the protein.

The detrimental effect of such poor-quality diets may be shown in three ways: (I) In the absence of an exciting infective agent, weight gain will be reduced by as much as $30 \%$ in the first 3 weeks of life. (2) The rate of build-up of 'infection' when large numbers of susceptible calves are passed successively through a calf house

\section{Table 3. Effect of heat treatment of milk on the calf}

Treatment of milk
$\begin{aligned} & \text { None } \\ & \text { Holder pasteurized }\left(63^{\circ} \text { for } 30 \mathrm{~min}\right)\end{aligned}$
$\begin{aligned} & \text { Spray-dried skim (preheating temperature } 77^{\circ} \\ & \text { for } 15 \mathrm{sec})\end{aligned}$
$\begin{aligned} & 23 \\ & \text { Spray-dried skim (preheating temperature } 74^{\circ}\end{aligned}$
$\begin{aligned} & \text { for at least } 3 \circ \mathrm{min}) \\ & \text { Roller-dried skim }\left(110^{\circ}\right)\end{aligned}$
$\left.\begin{array}{l}\text { UHT sterilized }\left(135^{\circ} \text { for } 1-3 \mathrm{sec}\right) \\ \text { on calf }\end{array}\right\} \begin{gathered}\text { Detrimental, especially during the first } 3 \\ \text { weeks of life }\end{gathered}$

will be greater (Roy, Palmer, Shillam, Ingram \& Wood, 1955). (3) The incidence of diarrhoea and mortality will be higher once the infection has been built up, as indicated by the dominance of one or two strains of $E$. coli (Wood, I955).

The distribution of diarrhoea over the first 3 weeks of life for calves given a 'severely' heat-treated milk is shown in Fig. $\mathbf{I}$; the incidence of diarrhoea declines markedly after 2 weeks of age.

To obtain further information on the effect of heat treatment of milk in predisposing calves to an $E$. coli localized intestinal infection, a study was made of the changes in the $\mathrm{N}$ composition of the pyloric and ileal outflow (Tagari \& Roy, I969,). The two diets studied contained spray-dried skim-milk powder 


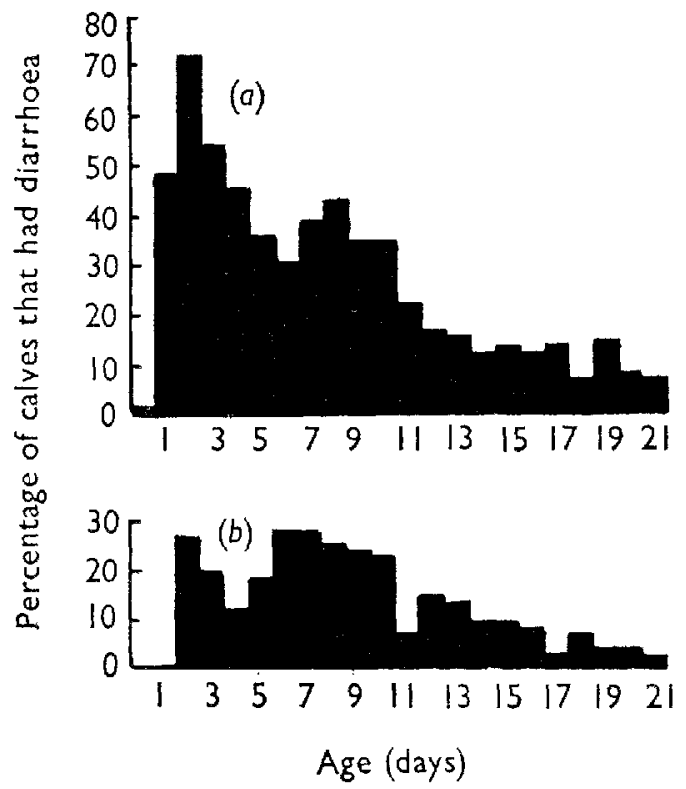

Fig. 1, Percentage of calves that had diarrhoea on each day during the first 3 weeks of life, when given a diet containing a 'severely' pre-heated spray-dried skim-milk powder after (a) $400 \mathrm{ml}$ or less of colostrum, (b) 3.41 . of colostrum.

that had been preheated either at $74^{\circ}$ for $3 \circ \mathrm{min}\left(\mathrm{milk} \mathrm{A}\right.$ ) or at $77^{\circ}$ for $15 \mathrm{sec}$ (milk $B)$. In milk $A$, about $50 \%$ of the non-casein protein nitrogen had been denatured compared with only about $10 \%$ in milk $B$.

The pyloric outflow with milk $B$ was of quite different appearance during the first $3 \mathrm{~h}$ after feeding from that with milk $\mathrm{A}$; the former had the appearance of clear whey, whereas the latter was milky in appearance and full of small pieces of clot. The average $\mathrm{pH}$ of the pyloric outflow with milk $\mathrm{B}$ was consistently lower than with milk $A$, the average values being 3.5 and 4.1 respectively. An increased volume of outflow occurred during the rst hour after feeding milk $B$ and only $39 \%$ of the total $\mathrm{N}$ in the pyloric outflow during the first $6.5 \mathrm{~h}$ after feeding was undigested protein $\mathrm{N}$ compared with $56 \%$ for milk $\mathrm{A}$. Not only was there an increased output of non-protein $\mathrm{N}$ from milk $\mathrm{B}$, but a very different pattern of flow. The peak flow of non-protein $N$ was reached very soon after feeding milk $B$, but not until about $3 \mathrm{~h}$ after milk $A$ was fed (Fig. 2).

These differences between milks $A$ and $B$ were associated with differences in the clotting characteristics. The addition of $\mathrm{Ca}$ to milk $\mathrm{A}$ in vitro resulted in an improved clot and an increase in whey drainage, but whey drainage was still much less than with milk $B$, especially during the first $3 \mathrm{~h}$ after addition of rennet. Similarly, in vivo studies showed that addition of $\mathrm{Ca}$ to milk $\mathrm{A}$ would not materially improve its quality for the calf (Shillam \& Roy, r963b). Addition of undenatured whey proteins appeared to be the only factor that would improve a severely heated skim-milk powder (Shillam et al. $1962 b$ ). This was in keeping with the findings of 


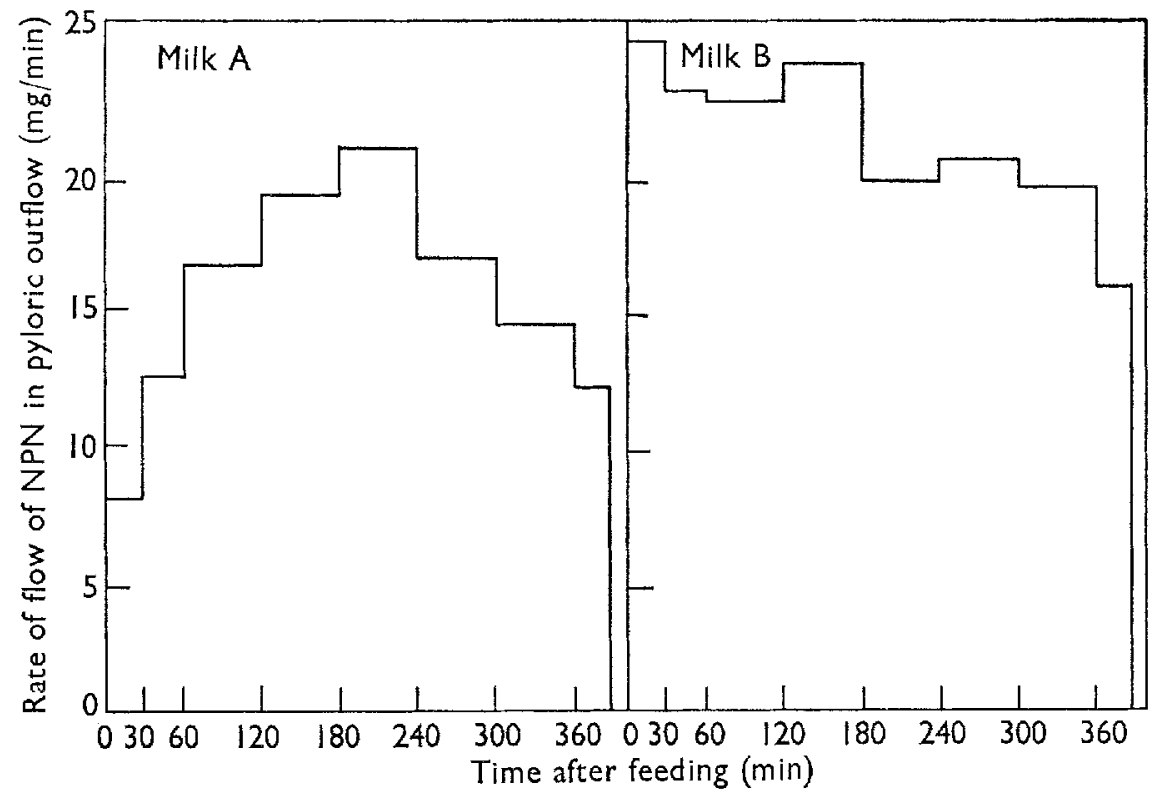

Fig. 2. Rate of flow of non-protein nitrogen (NPN) in pyloric outflow during $6.5 \mathrm{~h}$ after feeding calves with 3.5 1. of a diet containing a 'severely' preheated (milk A) or mildly preheated (milk B) spray-dried skim-milk powder (Tagari \& Roy, 1969).

Kannan \& Jenness ( 1961 ) that the presence of denatured whey proteins increased the rennet clotting time of casein.

Dehydrogenase activity was used by Tagari \& Roy (1969) as a measure of bacterial activity in the ileal contents, and was positively related to the $\mathrm{N}$ content, although no clear-cut difference in the $N$ concentration of the ileal contents from the two milks was apparent.

One calf had severe diarrhoea when given milk $A$ at a young age. This was associated with an increased pyloric outflow, an increased undigested protein outflow and a high average value for $\mathrm{pH}$ of $5 . \mathrm{I}$. In the ileal outflow, the volume of contents and weight of $\mathrm{N}$ were much increased, although the $\mathrm{N}$ concentration was much reduced. Mylrea ( 1968 ) has also shown a marked increase in the volume and quantities of reducing substances, $\mathrm{N}$, lipids and electrolytes in the ileal outflow of calves affected with non-specific enteritis.

It can thus be concluded that the detrimental effect of milk is largely associated with the high $\mathrm{pH}$ and poor digestibility of protein in the abomasum, which allows the multiplication of coliform organisms in the small intestine.

These experiments were done with Ayrshire calves, which tend to be more susceptible than Friesian calves. This finding may be related to the fact that the apparent digestibility of protein at the same weight and also at the same percentage of mature weight is significantly higher $(P<0.00 \mathrm{I})$ for Friesian than for Ayrshire or Jersey calves; at I $5 \%$ mature weight, our values were $94 . \mathrm{I}, 93.7$ and $95.8 \%$ for Jersey, Ayrshire and Friesian calves respectively. 
Further evidence of the importance of the $\mathrm{N}$ composition of the chyme in predisposing the older pre-ruminant calf to diarrhoea is shown by the negative relationship between the $\mathrm{N}$ percentage in the organic matter of the faeces and the drymatter content of the faeces (Fig. 3). The results shown in this figure are for milk diets, which either had received no heat treatment or had been 'mildly' preheated before drying. In general, calves given whole milk maintain a higher dry-matter

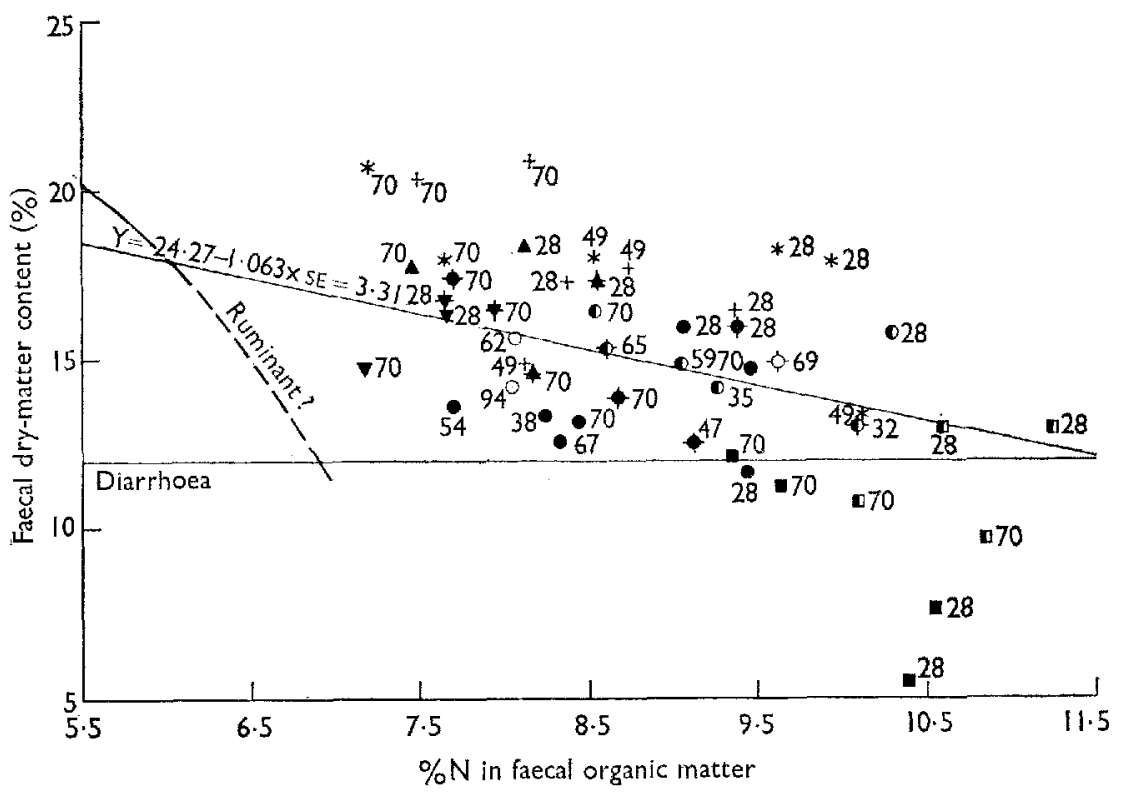

Fig. 3. Relationship (significant at $P<0.001$ ) between faccal dry-matter content $(\%)$ and nitrogen in faecal organic matter $(\%)$ for 243 collection periods from pre-ruminant calves of the Ayrshire, Friesian and Jersey breeds, given various milk diets ad lib. or at restricted levels. Diets had either no heat treatment or a 'mild' heat treatment (treatment means are given).

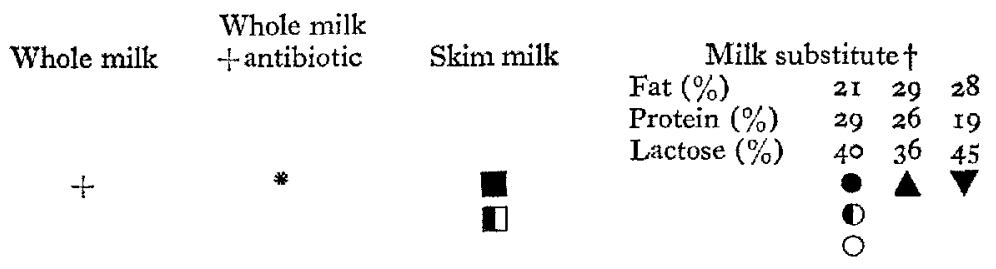

Numerals beside the points give age in days.

†Restricted intake (maintenance $+\mathrm{I} \mathrm{kg}$ gain/day) $(-,-)$

content in their faeces at the same percentage of $\mathrm{N}$ in the organic matter than calves given other liquid diets. Addition of chlortetracycline to whole milk tends to allow a higher faecal dry-matter content at high percentages of $\mathrm{N}$ in the organic matter, especially in the young calf. Skim milk alone causes a very low dry-matter content in the faeces, which at a young age is markedly lower for the Ayrshire than for the Friesian breed. In addition, at this age skim milk results in a lower faecal $\mathrm{pH}$ for the Ayrshire than for the Friesian (Table 4). Increasing the fat content of milk 
substitute diets tends to reduce the percentage of $\mathrm{N}$ in faecal organic matter and increase faecal dry-matter concentration.

Table 4. Comparison of dry-matter content of faeces in relation to $p H$ for Ayrshire and Friesian calves, aged 28-35 days, given liquid skim milk or a milk substitute containing $20 \%$ fat in the dry matter

\begin{tabular}{lcccc} 
& \multicolumn{2}{c}{ Liquid skim milk } & \multicolumn{2}{c}{ Milk substitute } \\
& Ayrshire & Friesian & Ayrshire & Friesian \\
Dry-matter content of faeces (\%) & $6 \cdot 5$ & $12 \cdot 9$ & $11 \cdot 6$ & $15 \cdot 8$ \\
pH of faeces & $6 \cdot 6$ & $8 \cdot 3$ & $7 \cdot 7$ & $7 \cdot 7$
\end{tabular}

We have, therefore, some evidence that putrefactive diarrhoea has probably similar underlying causes in both the pre-ruminant calf and the human infant. However, with infants, putrefactive diarrhoea tends to be associated with an increase in faecal $\mathrm{pH}$, whilst in pre-ruminant calves of 28 days of age and over faecal

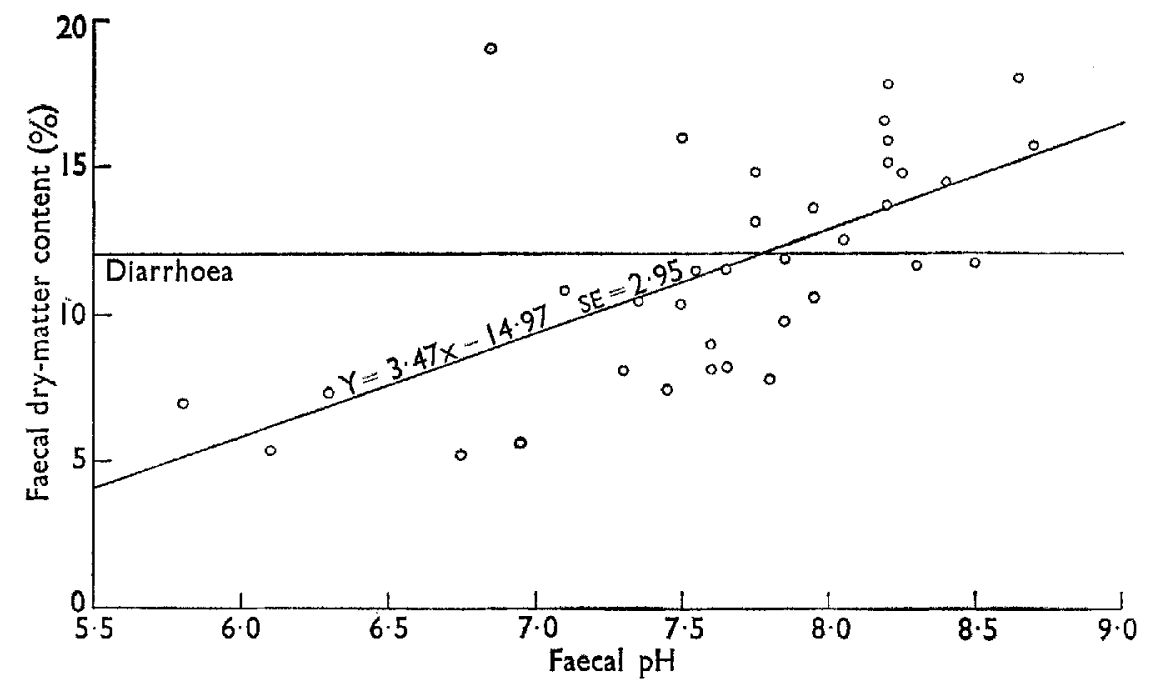

Fig. 4. Relationship (significant at $\mathrm{P}<0.001$ ) between faecal dry-matter content $(\%)$ and faecal pH for pre-ruminant calves of the Ayrshire and Friesian breeds.

$\mathrm{pH}$ tends to decline with increased moisture content of the faeces (Fig. 4). Mylrea (1968) found a lower $\mathrm{pH}$ in the jejunal and ileal contents of calves suffering from diarrhoea than in normal calves.

The clostridial diseases of lambs and calves have also been associated with the ingestion of large quantities of milk. Roberts (1938) demonstrated that Clostridium welchii is markedly susceptible to acidity and that after the ingestion of an abnormally large feed of milk, the casein renders the acid secretion of the abomasum inert for a sufficient time to allow the organism to proliferate and to produce toxin. The toxin is activated in the small intestine, where further proliferation and toxin production may also occur. 


\section{Fermentative diarrhoea in the pre-ruminant calf}

Fermentative diarrhoea has been associated with excessive carbohydrates in the diet or a deficiency of enzymes to degrade the carbohydrates present. The only sugars that can be utilized by the young calf are lactose and glucose, but even these sugars in too large a quantity are reported to cause diarrhoea (Rojas, Schweigert \& Rupel, 1948; Flipse, Huffman, Webster \& Duncan, r950; Cunningham $\&$ Brisson, 1957; Walker \& Faichney, 1964). The young pre-ruminant calf cannot digest starch, and thus the feeding of starch and its degradation products may also be responsible for diarrhoea.

Intakes greater than $200 \mathrm{~g}$ lactose and glucose per day caused the dry-matter content of faeces (fat-free basis) to fall below $10 \%$ (Blaxter \& Wood, 1953). In general, $9 \mathrm{~g} / \mathrm{kg}$ live weight of 'hexose equivalent' (for which calculation lactose values were converted into the equivalent weight of monosaccharide) tend to cause diarrhoea in lambs and calves (Walker \& Faichney, 1964 ). However, since a high content of carbohydrate in the diet is generally associated with a low content of fat, a 'hexose equivalent' of $12 \mathrm{~g} / \mathrm{kg}$ live weight may be fed to calves after the colostrum-feeding period, provided that the fat intake is about $5.5 \mathrm{~g} / \mathrm{kg}$ live weight.

\section{Diarrhoea in the ruminant}

The use of moisture content of faeces as an indicator of diarrhoea in the ruminant stage is less valid than for the pre-ruminant stage, as consistency of faeces is determined by the type of indigestible residues within them. Cattle on a high-roughage diet have apparently 'firm' faeces, but the moisture content may be considerably higher than that of 'loose' faeces from an animal receiving a high-concentrate diet. The loose faeces may be associated with a reduction in the dry-matter output rather than an increase in water output. Rook \& Balch (1959) showed that the decline in dry-matter content of faeces from 13 to $9 \%$, when cattle were changed from a diet of silage, hay and concentrates to one of young Cocksfoot herbage, was associated with an actual decline in faecal water output and an even greater fall in faecal drymatter output.

Although the ruminant can exhibit diarrhoea on diets excessively high in protein or carbohydrate, probably as a result of changes in the composition of the chyme, Sineschekov (1965) has shown that in cattle, irrespective of the composition of the diet, the composition of duodenal chyme distal to the pancreatic duct remains remarkably constant in composition, particularly in relation to ash and $\mathrm{N}$ content. For instance, with diets containing $I_{4}$ or $25 \%$ protein, the chyme contained $0.13 \% \mathrm{~N}$. $\mathrm{He}$ found that, in cattle fed various diets, the $\mathrm{N}$ content of chyme varied only from 0.1 to $0.2 \%$.

There is however a tendency for diarrhoea to be associated with too low or too high a percentage of $\mathrm{N}$ in the faecal organic matter (Fig. 5). The curve that has been fitted to these values is of interest in that the normal range of $\% \mathrm{~N}$ in organic matter of duodenal chyme in ruminant cattle, found by Sineschekov (1965), occurs in the area of highest faecal dry-matter content. The reticulo-rumen probably plays an 


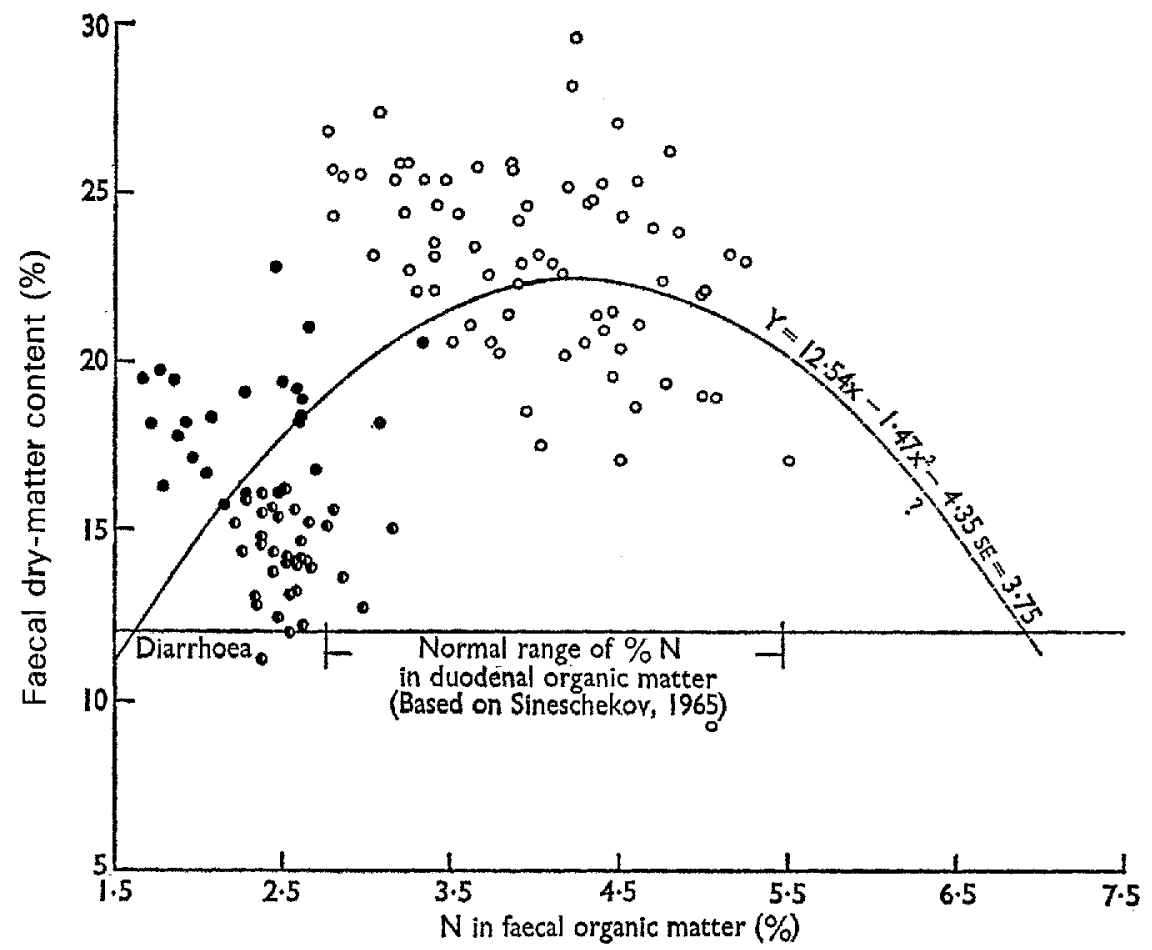

Fig. 5. Relationship (significant at $\mathrm{P}<0.001$ ) between faecal dry-matter content $(\%)$ and $\mathrm{N}$ in faecal organic matter $(\%)$ for 131 collection periods from young ruminant cattle of the Friesian and Ayrshire breeds. 9 , high-roughage diet; 0 , high-concentrate diet; $\mathbf{O}$, high-carbohydrate diet.

important part in preventing the passage of excessive amounts of $\mathrm{N}$ into the intestine, and thus the ruminant animal is not normally very susceptible to putrefactive diarrhoea. Broberg (1956) showed that excessive protein feeding was associated with diarrhoea and caused a marked rise in the number of $E$. coli in the rumen. Seekles (1956) also associated enteric disorders with the feeding of diets very rich in proteins and peptides; such diets allow the migration of bacteria from the large to the small intestine, causing autotoxication as a result of the amines and toxins produced. Intestinal protein loss in chronic diarrhoeal conditions in cattle is possibly associated with lymphatic abnormalities in the mucosa, similar to that found in man (Nielsen \& Andersen, 1967 ).

In contrast to what has been found in the pre-ruminant stage, clostridial infections in the ruminant animal have been associated with overeating of carbohydrate and a flow of unfermented starch from the rumen into the small intestine, where the starch will form a favourable medium for production of toxin (Bullen \& Battey, 1957).

\section{Conclusion}

From the available evidence, it would appear that the composition of the chyme in the ruminant is of great importance in maintaining a balanced bacterial flora 
and in preventing diarrhoea. However, only the effects of dietary $\mathrm{N}$ and carbohydrate have been considered. Diarrhoea associated with excess and deficiency of minerals, and with vitamin deficiencies, is beyond the scope of this paper.

\section{REFERENCES}

Blaxter, K. L. \& Wood, W. A. (I953). Vet. Rec. 65, 889.

Broberg, G. (1956). Nord. VetMed. 8, 935.

Bullen, J. J. \& Battey, I. (1957). Vet. Rec. 69, 1268.

Cunningham, H. M. \& Brisson, G. J. (1957). Can. Y. Anim. Sci. 37, 52.

Fisher, E. W. (1965). Br. vet. Я. 12r, 132.

Fisher, E. W. \& McEwan, A. D. (1967). Br. ver. F. 123, 4.

Flipse, R. J., Huffman, C. F., Webster, H. D. \& Duncan, C. W. (I950). Y. Dairy Sci. 33, 548.

Ingram, P. L. (1962). Observations on the pathology and pathogenesis of experimental colibacillosis in calves. PhD Thesis, University of London.

Kannan, A. \& Jenness, R. (1961). \%. Dairy Sci. 44, 808.

Leech, F. B., Macrae, W. D. \& Menzies, D. W. (1968). Calf Wastage and Husbandry in Britain 1962-3. London: H.M. Stationery Office.

Mylrea, P. J. (1968). Res. vet. Sci. 9, 14.

Nielsen, K. \& Andersen, S. (1967). Nord. VetMed. 19, 3 r.

Roberts, R. S. (1938). Vet. Rec. 50, 591.

Rojas, J., Schweigert, B. S. \& Rupel, I. W. (1948). F. Dairy Sci. 31, 8 I.

Rook, J. A. F. \& Balch, C. C. (1959). Proc. Nutr. Soc. 18, xxxv,

Roy, J. H. B. (1956). Studies in calf nutrition with special reference to the protective action of colostrum. PhD Thesis, University of Reading.

Roy, J. H. B. (1964). Vet. Rec. 76, 5 II.

Roy, J. H. B., Palmer, J., Shillam, K. W. G., Ingram, P. L. \& Wood, P. C. (1955). Br. F. Nutr. 9, ir.

Schultze, H. E. \& Heremans, J. F. (I g66). Molecular Biology of Human Proteins. Vol. I. London and New York: Elsevier Publishing Co.

Seekles, L. (1956). Nutrition Tetany in Dairy Cattle. (Mimeo.) University of Utrecht.

Shillam, K. W. G., Dawson, D. A. \& Roy, J. H. B. (r g60). Br. F. Nutr. 14, 403.

Shillam, K. W. G. \& Roy, J. H. B. (I961). Int. Congr. Anim. Prod. vir. Hamburg 3, 276.

Shillam, K. W. G. \& Roy, J. H. B. (1963a). Br. F. Nutr. 17, I7 I.

Shillam, K. W. G. \& Roy, J. H. B. $\left(1^{96} 6_{3} b\right)$. Br. $\mathcal{F}$. Nutr. 17, 183.

Shillam, K. W. G. \& Roy, J. H. B. (I963c). Br. Э. Nutr. 17, 193.

Shillam, K. W. G., Roy, J. H. B. \& Ingram, P. L. (1962a). Br. F. Nutr. 16, 267.

Shillam, K. W. G., Roy, J. H. B. \& Ingram, P. L. (1962b). Br. Y. Nutr. 16, 585 .

Shillam, K. W. G., Roy, J. H. B. \& Ingram, P. L. (1962c). Br. Y. Nutr. 16, 593 .

Sineschekov, A. D. (1965). The Biology of Nutrition of Farm Animals. Biological Bases of Rational Feed Utilization. Moscow: Kolos Publishing House.

Smith, H. W. (1965). 7. Path. Bact. 9o, 495.

Tagari, H. \& Roy, J. H. B. (1969). Br. F. Nutr. 23. (In the Press.)

Veterinary Investigation Service. (1964). Vet. Rec. 76, 1139.

Walker, D. M. \& Faichney, G. J. (1964). Br. F. Nutr. 18, 209.

Weijers, H. A. \& van de Kamer, J. H. (1965). Nutr. Abstr. Rev. 35, 59 r.

Werner, B. (1948). Acta paediat., Stockh. 35, Suppl. 6.

Wood, P. C. (1955). J. Path. Bact. 70, r79. 